\title{
ANALISIS AKTIVITAS ANTIOKSIDAN PADA SEDIAAN MASKER WAJAH KULIT BUAH DELIMA MERAH (PUNICA GRANATUM L.) MELALUI REAKSI ANTARA EKSTRAKNYA DENGAN 1,1-DIFENIL- 2-PIKRILHIDRAZIL (DPPH) DAN TINJAUANNYA MENURUT PANDANGAN ISLAM
}

Nurul A'fiyah Salsabila, Sri Utami dan Arsyad

Universitas Yarsi, Indonesia

E-mail: nurulsalsabila121198@gmail.com,uutsuyono@yahoo.com dan muhammad.arsyad@yarsi.ac.id

\section{Diterima:}

05 Desember 2021

Direvisi:

12 Desember 2021

\section{Disetujui:}

15 Desember

2021

\section{Abstrak}

Latar Belakang: Senyawa radikal bebas sering kita jumpai pada kehidupan sehari-hari yang dapat berdampak buruk terhadap kulit. Antioksidan dibutuhkan untuk meredam senyawa radikal bebas terhadap kulit. Buah delima merah merupakan buah yang terdapat dalam Al-Qur' an dengan antoksidan berupa flavonoida, asam fenolat dan tanin. Penuaan kulit dapat dicegah dengan menggunakan masker wajah yang mengandung antioksidan. Tujuan: Mengetahui aktivitas antioksidan pada kulit delima merah dalam bentuk masker wajah bubuk melalui reaksi antara ekstraknya dan mengetahui tinjauannya menurut pandangan Islam terhadap kulit buah delima merah yang diolah menjadi masker wajah dan diuji aktivitas antioksidannya dengan metode DPPH. Metode: Kulit delima merah dikeringkan, kemudian digerus dengan blender agar mendapatkan bubuk kulit delima merah. Bubuk kulit delima merah yang telah diperoleh direndam dengan etanol $70 \%$, lalu disaring dan filtratnya dipekatkan menggunakan vacuum rotary evaporator sehingga didapatkan ekstrak kental yang selanjutnya dikeringkan dengan menggunakan oven sehingga didapatkan ekstrak bubuk kulit delima merah. Penetapan aktivitas antioksidan ini dilakukan melalui pendekatan pengukurannya terhadap ekstraknya karena masker wajah yang merupakan bubuk kulit delima merah tidak dapat ditetapkan dengan metode DPPH. Hasil: Aktivitas antioksidan dinyatakan dengan nilai $\mathrm{IC}_{50}$ pada kulit delima merah yang dijadikan masker wajah bubuk mempunyai nilai $\mathrm{IC}_{50}$ sebesar 8,33 ppm sedangkan asam askorbat sebagai kontrol positif memiliki nilai $\mathrm{IC}_{50}$ sebesar $2,98 \mathrm{ppm}$. Kesimpulan: Ekstrak kulit delima merah mempunyai aktivitas antioksidan dan termasuk kategori antioksidan yang sangat kuat dan penelitian ini sejalan dengan perintah Allah SWT yang menyarankan umatnya untuk menjaga kesehatan dan kecantikan diri.

Kata kunci: Antioksidan, DPPH, Delima merah (Punica granatum L.), Ekstrak kulit delima merah, $\mathrm{IC}_{50}$ (inhibitory concentration 50), Masker wajah bubuk

\section{Abstract}

Background: We can find free radical substances all around that will give us negative impact on our health particularly our skin. Antioxidant is needed to neutralize the effect of free 


\section{Pendahuluan}

Senyawa radikal bebas sering kita jumpai pada kehidupan sehari-hari yang dapat berdampak buruk terhadap kulit. Senyawa ini merupakan molekul yang memiliki satu atau lebih elektron yang tidak berpasangan (Lepir \& Hadiwibowo, 2019). Elektron yang tidak berpasangan menyebabkan radikal bebas menjadi senyawa yang sangat reaktif terhadap sel-sel tubuh sehingga partikel tidak berpasangan mencari pasangan dengan cara mengikat elektron molekul sel (Sunaryo et al., 2016). Radikal bebas dalam jumlah normal bermanfaat bagi kesehatan sementara dalam jumlah berlebih mengakibatkan stres oksidatif (Hadinata, 2015).

Antioksidan adalah senyawa yang dapat menangkal atau meredam dampak negatif oksidan. Antioksidan bekerja dengan cara mendonorkan satu elektronnya kepada senyawa yang bersifat oksidan sehingga dapat menghambat aktivitas senyawa oksidan (Sayuti \& Yenrina, 2015). Antioksidan berfungsi melindungi tubuh dengan mengatasi dan menetralisir radikal bebas, baik secara endogen maupun eksogen (Andarina \& Djauhari, 2017). Secara alami tubuh mampu menghasilkan antioksidan, akan tetapi kemampuan ini ada batasnya (Fauzi, 2018). Kemampuan tubuh untuk memproduksi antioksidan alami akan semakin berkurang, dengan bertambahnya usia, oleh karena itu penambahan antioksidan dari luar masih diperlukan (Siagian, 2013).

Tanaman dan buah-buahan terbukti berpotensi sebagai antioksidan karena mengandung berbagai zat seperti karoten, flavonoida dan komponen fenolik lain, serta vitamin C dan vitamin (Riris, 2018). Buah delima merah (Punica granatum L.) 
merupakan salah satu buah yang memiliki senyawa fenolik atau polifenolik yang termasuk dalam golongan flavonoida (Probosari, 2015). Senyawa flavonoida sering diketahui manfaatnya sebagai antioksidan, khususnya penangkap radikal bebas. Salah satu artikel jurnal pernah menyatakan bahwa kemampuan antioksidan dari flavonoida yaitu dapat mengurangi pembentukan radikal bebas dan menangkap radikal bebas (Pietta, 2000). Salah satu penelitian membuktikan nilai TEAC (trolox equivalent antioxidant capacity) kulit delima merah memiliki nilai tertinggi dibandingkan bunga, daun, batang, dan biji buah delima (Rummun, Somanah, Ramsaha, Bahorun, \& Neergheen-Bhujun, 2013).

Pemeliharaan kulit memerlukan perhatian yang khusus karena kulit merupakan organ yang sensitif terhadap perlakuan dan rangsangan. Salah satu masalah saat ini yang berkaitan dengan kulit yaitu penuaan dini. Penggunaan antioksidan diharapkan dapat menghambat proses penuaan kulit serta dapat mencegah kerusakan tubuh dari timbulnya penyakit degeneratif (Yuslianti, 2018). Pemakaian masker wajah adalah salah satu usaha yang sering dilakukan untuk membantu mencegah penuaan dini dan mengurangi munculnya keriput dan garis-garis halus (AF, Widodo, \& Widyarti, 2016). Masker bubuk merupakan masker berbahan alami yang tidak banyak mendapatkan campuran tambahan apapun, sehingga lebih aman untuk digunakan.

Salah satu metode yang dapat digunakan untuk menentukan aktivitas antioksidan adalah dengan menggunakan radikal bebas DPPH. Metode DPPH digunakan untuk menguji kemampuan suatu komponen sebagai penangkap radikal bebas (Rorong, 2019).

Menurut pandangan Islam buah delima merah merupakan buah yang bagus untuk dikonsumsi dan merupakan buah yang disebutkan beberapa kali dalam Al-Quran yang terdapat pada surah QS. Al-An'am ayat 99, Q.S Al- A'raf ayat 26, dan QS. Ar-Rahman ayat 68. Menurut Muhammad Thabathaba'i dalam kitab Tafsir al Mizan Fi Tafsir alQur'an bahwa buah delima berdekatan dengan buah kurma di surga dan merupakan buah yang banyak manfaat. Selain itu islam menganjurkan dan tidak melarang umat nya untuk merawat diri dengan melalukan upaya menjaga kecantikan. Berbagai penelitian telah banyak dilakukan untuk mengetahui komposisi dan kandungan yang terdapat dalam buah tersebut. Buah-buahan yang disebutkan dalam Al-Qur'an selain bagus untuk dikonsumsi, juga memiliki manfaat bagi kesehatan tubuh.

\section{Metode Penelitian}

Alat

Blender, kertas saring (Whatman No.41 diameter $125 \mathrm{~mm}$ ), labu erlenmeyer, kuvet $1 \times 1 \mathrm{~cm}^{2}$, tabung reaksi, spektrofotometer UV-Vis (Shimadzu UV-1800), vacuum rotary evaporator (Buchi rotavapor R-300 Pro), timbangan (Nagako), timbangan analitik (Sartorius BSA224S-CW), shaker (IKA KS 260), oven, mikropipet dan aluminium foil.

\section{Bahan}

Kulit delima merah, asam askorbat (kontrol positif), metanol, etanol 70\% dan DPPH.

\section{Pembuatan Ekstrak Etanol 70\% dari Kulit Delima Merah}

Kulit delima merah yang telah dibersihkan dipotong kecil-kecil lalu dikeringkan dengan cara diangin-anginkan kemudian diserbukkan dengan blender sehingga didapatkan hasil bubuk kulit delima merah halus. Bubuk kulit delima merah halus sebanyak $105 \mathrm{~g}$ dimasukkan ke dalam tabung erlenmeyer $(500 \mathrm{~mL})$ kemudian di maserasi menggunakan $500 \mathrm{~mL}$ pelarut etanol $70 \%$ dan dipusingkan selama 10 jam dengan menggunakan shaker. Rendaman tersebut disaring menggunakan kertas saring sehingga 
diperoleh filtrat dan residu. Pelarut etanol 70\% ditambahkan kembali sebanyak $500 \mathrm{~mL}$ ke dalam tabung erlenmeyer yang berisi residu, dan didiamkan selama 24 jam. Seterusnya, dilakukan dengan cara yang sama selama 3 hari. Hasil maserasi diuapkan dengan menggunakan vacuum rotary evaporator suhu 50o $\mathrm{C}$ sehingga diperoleh ekstrak kental, kemudian dikeringkan dengan menggunakan oven pada suhu 105 o C selama 9 jam hingga diperoleh ekstrak etanol kering dalam bentuk bubuk (Handayani et al., 2014; Sutriandi et al., 2016). Sampel ekstrak kering kulit delima merah ditimbang sebanyak 10 $\mathrm{mg}$ dan dilarutkan dengan metanol hingga volumenya $10 \mathrm{~mL}$. Larutan ekstrak yang tersedia menjadi larutan stok dengan konsentrasi $1000 \mathrm{ppm}$.

\section{Pembuatan Larutan DPPH}

DPPH dengan konsentrasi $160 \mathrm{mg} / \mathrm{L}$ dibuat dengan menimbang zat tersebut sebanyak 4,0 mg dan dilarutkan dalam $25 \mathrm{~mL}$ metanol di dalam labu ukur. Larutan yang dihasilkan disimpan di ruang gelap dan dilindungi dengan aluminium foil.

\section{Pengukuran Aktivitas Antioksidan Ekstrak Etanol Kulit Delima Merah}

Pengujian dilakukan dengan memipet $4 \mathrm{~mL}$ larutan sampel dari berbagai konsentrasi (0 ppm, 10 ppm, 25 ppm, 50 ppm, 100 ppm dan 200 ppm). Masing-masing konsentrasi ditambah $1 \mathrm{~mL}$ DPPH. Kemudian, dihomogenkan dan diinkubasi pada suhu kamar pada ruangan gelap selama 30 menit. Absorbansi diukur pada panjang gelombang $517 \mathrm{~nm}$ dan masing-masing konsentrasi dibuat 3 kali pengulangan.

\section{Pembuatan Larutan Asam Askorbat}

Asam askorbat digunakan sebagai kontrol positif. Asam askorbat baku ditimbang sebanyak $11 \mathrm{mg}$ dan dilarutkan dalam $11 \mathrm{~mL}$ metanol sehingga didapat larutan induk asam askorbat dengan konsentrasi $1000 \mathrm{ppm}$. Dari larutan induk tersebut, dibuat konsentrasi 1 ppm, 2 ppm, 3 ppm, 4 ppm, dan 5 ppm dengan menggunakan mikropipet kedalam labu ukur dan masing-masing konsentrasi dibuat 3 kali pengulangan.

\section{Perhitungan $\mathrm{IC}_{50}$}

Nilai IC50 merupakan nilai yang menggambarkan besarnya konsentrasi dari ekstrak uji yang dapat menangkap radikal bebas sebesar 50\%. Nilai ini didapat melalui persamaan garis regresi linier yang menyatakan hubungan antara konsentrasi senyawa uji (sumbu $\mathrm{x}$ ) dengan persen aktivitas penangkap atau \% inhibisi (sumbu y). Dari data tersebut diperoleh persamaan $y=b x+a$ dengan a sebagai intersep, $b$ sebagai slope dan nilai koefisien korelasi dinyatakan sebagai r2. Dari persamaan diatas dapat dirumuskan menjadi:

$$
\mathrm{IC}_{50}=\frac{50-\mathrm{a}}{\mathrm{b}}
$$

Nilai $r$ yang baik mendekati -1 atau +1 tergantung pada nilai slope yang diperoleh (Nurliyana, Syed Zahir, Mustapha Suleiman, Aisyah, \& Kamarul Rahim, 2010).

Pengenceran sampel uji dengan DPPH dilakukan sesuai dengan Tabel 1. Semua larutan dimasukkan ke dalam tabung reaksi, lalu diinkubasi pada suhu kamar selama 30 menit yang dihitung sejak penambahan larutan DPPH pada sampel. Kemudian diukur serapannya pada panjang gelombang maksimal DPPH $(517 \mathrm{~nm})$. Persentase inhibisi aktivitas antioksidan dapat dihitung melalui rumus: 


$$
\% \text { Inhibisi }=\frac{A_{0}-A_{1}}{A_{0}} \times 100 \%
$$

Keterangan: $\quad \mathrm{A}_{0}=$ absorbansi blanko (metanol)

Tabel 1. Pengenceran Sampel Uji dengan DPPH

\begin{tabular}{cccc}
\hline \hline Konsentrasi (ppm) & $\begin{array}{c}\text { Larutan } \\
\text { Sampel }(\mu \mathrm{L})\end{array}$ & Metanol $(\mu \mathrm{L})$ & $\begin{array}{c}\text { DPPH 160 } \\
\mathrm{ppm}(\mu \mathrm{L})\end{array}$ \\
\hline Blanko & 0 & 4000 & 1000 \\
10 & 50 & 3950 & 1000 \\
25 & 125 & 3875 & 1000 \\
50 & 250 & 3750 & 1000 \\
100 & 500 & 3500 & 1000 \\
200 & 1000 & 3000 & 1000 \\
\hline
\end{tabular}

Pengujian dilakukan tiga kali perulangan (triplo, $\mathrm{n}=3$ ). Pada penelitian ini analisis statistik yang digunakan menggunakan uji t dengan bantuan program SPSS.

\section{Hasil dan Pembahasan}

\section{Penyiapan Sampel Bubuk Halus Kulit Delima Merah}

Sebanyak tujuh buah delima merah yang telah diperoleh dicuci dengan air keran yang mengalir, dikupas dan diambil kulitnya kemudian dipotong kecil-kecil sehingga diperoleh berat $420 \mathrm{~g}$. Kulit yang telah diperoleh akan dikeringkan dengan cara dianginanginkan selama 3 hari dan didapatkan berat kering kulit delima merah sebanyak $280 \mathrm{~g}$. Kulit delima merah yang telah kering akan di-blender sampai menjadi bubuk. Bubuk kulit delima merah yang halus dipisahkan dari bubuk yang kasar. Bubuk kulit delima merah halus didapatkan sebanyak $105 \mathrm{~g}$.

\section{Pembuatan Ekstrak Bubuk Halus Kulit Delima Merah}

Ekstraksi bubuk kulit delima merah menggunakan metode maserasi dengan etanol $70 \%$ sebagai pelarut. Hasil dari proses maserasi berupa filtrat berwarna cokelat, kemudian disaring menggunakan kertas saring dan filtratnya dipekatkan. Pemekatan filtrat dilakukan dengan menggunakan vacuum rotary evaporator untuk memperoleh ekstrak kental. Ekstrak kental yang didapat berwarna cokelat dengan berat 30,4343 g. Ekstrak kental akan dikeringkan menggunakan oven dengan suhu $1050 \mathrm{C}$ selama 9 jam sehingga diperoleh ekstrak kering bubuk kulit delima merah dengan berat 7,3201 g. Dari hasil proses maserasi diperoleh rendemen ekstrak. Rendemen adalah perbandingan antara ekstrak yang diperoleh dengan simplisia awal dengan menggunakan satuan persen (\%) (Wijaya \& Novitasari, 2018), sehingga didapatkan nilai rendemen ekstrak dari ekstrak etanol sebanyak $28,98 \%$ dan bubuk kulit delima merah mengalami penyusutan $23,1 \mathrm{~g}$. 


\section{Uji Aktivitas Antioksidan Menggunakan Metode DPPH \\ Spektrofotometer UV-Vis}

Prinsip dari metode uji aktivitas antioksidan ini adalah pengukuran aktivitas antioksidan secara kuantitatif yaitu dengan melakukan pengukuran penangkapan radikal DPPH oleh suatu senyawa yang mempunyai aktivitas antioksidan dengan menggunakan spektrofotometer UV-Vis, sehingga dengan demikian akan diketahui nilai aktivitas peredaman radikal bebas yang dinyatakan dengan nilai IC50. Teknik pengolahan data dilakukan dengan membandingkan konsentrasi dan aktivitas penghambatan atau \% inhibisi masing-masing sampel dalam sebuah grafik regresi. Hasil uji antioksidan dapat dilihat pada Tabel 2.

Tabel 2. Persen Inhibisi Ekstrak Bubuk Kulit Delima Merah dan Kontrol Positif

\begin{tabular}{|c|c|c|c|c|c|c|}
\hline \multirow{2}{*}{ Sampel } & \multirow{2}{*}{$\begin{array}{l}\text { Konsentrasi } \\
\quad(\mathrm{ppm})\end{array}$} & \multicolumn{3}{|c|}{ Absorbansi } & \multirow{2}{*}{$\begin{array}{l}\text { Rata-Rata } \\
\text { Absorbansi }\end{array}$} & \multirow{2}{*}{$\begin{array}{c}\text { Persen } \\
\text { Inhibisi } \\
(\%)\end{array}$} \\
\hline & & Data 1 & Data 2 & Data 3 & & \\
\hline \multirow{6}{*}{$\begin{array}{c}\text { Ekstrak } \\
\text { Bubuk } \\
\text { Kulit } \\
\text { Delima } \\
\text { Merah }\end{array}$} & 0 & 0,685 & 0,681 & 0,705 & 0,705 & \\
\hline & 0,5 & 0,666 & 0,664 & 0,673 & 0,667 & 3,27 \\
\hline & 1 & 0,657 & 0,655 & 0,665 & 0,655 & 4,52 \\
\hline & 2 & 0,626 & 0,625 & 0,618 & 0,623 & 9,72 \\
\hline & 4 & 0,523 & 0,528 & 0,53 & 0,527 & 23,64 \\
\hline & 8 & 0,357 & 0,367 & 0,349 & 0,357 & 48,16 \\
\hline \multirow{6}{*}{$\begin{array}{l}\text { Asam } \\
\text { Askorbat } \\
\text { (Kontrol } \\
\text { Positif) }\end{array}$} & 0 & 0,874 & 0,874 & 0,874 & 0,874 & \\
\hline & 1 & 0,672 & 0,692 & 0,672 & 0,678 & 22,34 \\
\hline & 2 & 0,565 & 0,591 & 0,591 & 0,582 & 33,37 \\
\hline & 3 & 0,407 & 0,439 & 0,459 & 0,435 & 50,99 \\
\hline & 4 & 0,299 & 0,310 & 0,310 & 0,306 & 64,95 \\
\hline & 5 & 0,191 & 0,173 & 0,173 & 0,179 & 79,52 \\
\hline
\end{tabular}

Dengan memasukkan variasi sebagai nilai/sumbu x dengan inhibisiradikal bebas sebagai nilai/sumbu didapatkan persamaan regresi linier untuk memperoleh nilai IC50. Nilai IC50 merupakan konsentrasi efektif yang dibutuhkan untuk meredam 50\% dari total radikal bebas yaitu DPPH sehingga didapatkan persamaan regresi linier seperti pada Tabel 3. 
Tabel 3. Nilai $\mathrm{IC}_{50}$ Sampel Uji

\begin{tabular}{ccccc}
\hline Sampel & $\begin{array}{c}\text { Persamaan Regresi } \\
\text { Linear }\end{array}$ & $\mathbf{r}^{2}$ & $\begin{array}{c}\mathbf{I C}_{\mathbf{5 0}} \\
(\mathbf{p p m})\end{array}$ & $\begin{array}{c}\text { Standar } \\
\text { Deviasi }\end{array}$ \\
\hline $\begin{array}{c}\text { Ekstrak Bubuk Kulit } \\
\text { Delima Merah }\end{array}$ & $\mathrm{y}=11,975 \mathrm{x}+4,0616$ & 0,9965 & 8,33 & 0,36 \\
\hline & & & & \\
Asam Askorbat & $\mathrm{y}=14,592 \mathrm{x}+6,4607$ & 0,9950 & 2,98 & 0,06 \\
& & & & \\
\hline
\end{tabular}

Kuat atau lemahnya aktivitas antioksidan pada suatu sampel uji ditentukan dengan parameter nilai IC50. Berikut terdapat sifat antioksidan berdasarkan nilai IC50 menurut Molyneux.

Tabel 4. Sifat Antioksidan Berdasarkan Nilai IC I0 $_{50}$ (Molyneux, 2004)

\begin{tabular}{cc}
\hline \hline Nilai $\mathbf{I C}_{\mathbf{5 0}}$ & Sifat Antioksidan \\
\hline$<50 \mathrm{ppm}$ & Sangat Kuat \\
$50 \mathrm{ppm}-100 \mathrm{ppm}$ & Kuat \\
$100 \mathrm{ppm}-150 \mathrm{ppm}$ & Sedang \\
$150 \mathrm{ppm}-200 \mathrm{ppm}$ & Lemah \\
\hline
\end{tabular}

Berdasarkan tabel di atas, nilai IC50 dari ekstrak kulit delima merah kurang dari 50 ppm menunjukkan bahwa ekstrak bubuk kulit delima merah dan asam askorbat merupakan antioksidan sangat kuat.

Nilai $\mathrm{r}$ yang mendekati +1 (bernilai positif) menggambarkan bahwa dengan meningkatnya konsentrasi sampel uji maka semakin besar aktivitas antioksidannya, hal ini dapat dilihat dari kurva hubungan konsentrasi ekstrak kulit delima merah terhadap \% inhibisi seperti pada kurva regresi linier sebagai berikut:

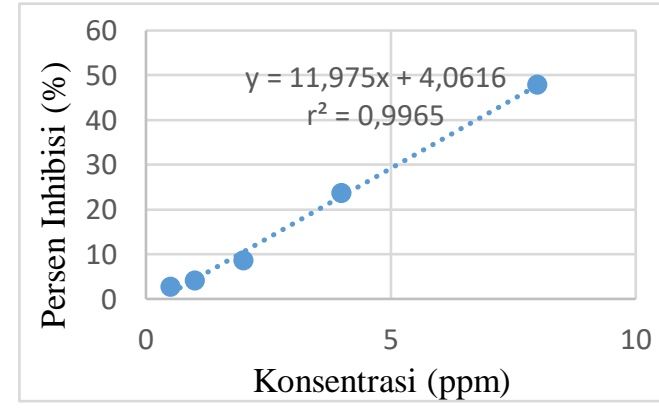

(a)

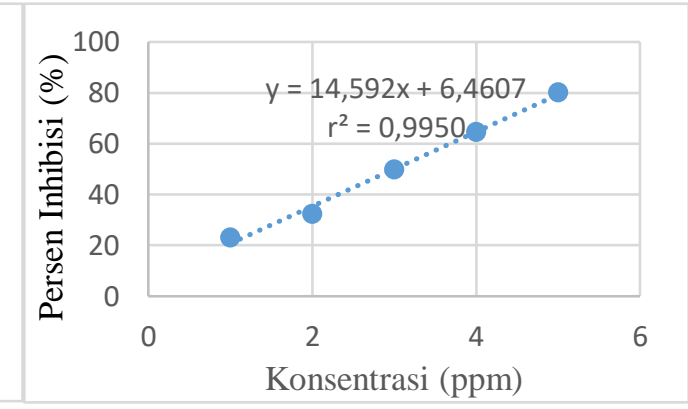

(b)

Gambar 1. Kurva Hubungan Konsentrasi dengan \% Inhibisi dengan Variasi Sampel (a) Ekstrak Kulit Delima Merah (b) Asam Askorbat 


\section{Analisis Data Penelitian Persen Inhibisi}

Dalam pengolahan data dilakukan uji parametrik yang memiliki empat kriteria yang harus dipenuhi, yaitu:

1. Sampel diambil secara acak (random);

2. Data mempunyai skala interval atau rasio;

3. Data terdistribusi secara normal;

4. Data mempunyai variance yang sama. (Dahlan, 2008).

5. Sampel uji yang diambil merupakan buah delima yang dipilih secara acak tetapi disortasi berdasarkan mutu terbaik. Dengan demikian, memenuhi kriteria uji parametrik pertama. Data yang diperoleh merupakan data numerik yang termasuk data dengan skala rasio. Dengan demikian, memenuhi kriteria uji parametrik kedua.

Tabel 5. Hasil Uji Normalitas Persen Inhibisi Menggunakan Uji Kolmogrov-Smirnov

\begin{tabular}{ccc}
\hline Sampel & Kolmogorov-Smirnov & $\boldsymbol{p}$-value \\
\hline Kulit Delima Merah & 0,913 & 0,376 \\
\hline Asam Askorbat & 0,605 & 0,857 \\
\hline
\end{tabular}

Berdasarkan uji Kolmogorov-Smirnov di atas, didapatkan nilai p-value > 0,05 terhadap kedua sampel maka data berdistribusi normal. Dengan demikian, memenuhi kriteria uji parametrik ketiga.

Tabel 6. Hasil Uji Homogenitas Varians Persen Inhibisi dengan Uji Levene's test

\begin{tabular}{cc}
\hline Sampel & $\boldsymbol{p}$-value \\
\hline Kulit Delima Merah & 0,355 \\
\hline Asam Askorbat & 0,780 \\
\hline
\end{tabular}

Pada uji homogenitas menggunakan uji Levene's test didapatkan nilai p-value > 0,05 maka dapat disimpulkan bahwa varians dari dua kelompok populasi adalah sama (homogen). Dengan demikian, data tersebut memenuhi kriteria uji parametrik keempat.

Tabel 7. Hasil Uji t Persen Inhibisi

\begin{tabular}{ccc}
\hline Sampel & $\mathrm{t}$ & p-value \\
\hline Kulit Delima Merah & 31,467 & \multirow{2}{*}{0,000} \\
\hline Asam Askorbat & 55,688 & \\
\hline
\end{tabular}

Berdasarkan hasil perhitungan, dapat dilihat bahwa didapatkan nilai p-value $<0,05$ yang berarti persen inhibisi sediaan bubuk kulit delima merah dengan asam askorbat memiliki perbedaan yang signifikan. Persent inhibisi didapat dari absorbansi masingmasing sampel, di mana persen inhibisi berbanding lurus dengan absorbansi.

\section{Analisis Data Nilai IC $_{50}$}

Sampel uji yang diambil merupakan buah delima yang dipilih secara acak tetapi disortasi berdasarkan mutu terbaik. Dengan demikian, sampel uji memenuhi kriteria uji parametrik pertama. Data yang diperoleh merupakan data numerik yang termasuk data 
dengan skala rasio. Dengan demikian, data tersebut memenuhi kriteria uji parametrik kedua.

Tabel 8. Hasil Uji Normalitas Nilai IC $_{50}$ Menggunakan Uji Kolmogorov-Smirnov

\begin{tabular}{ccc}
\hline \hline Sampel & Kolmogorov-Smirnov & p-value \\
\hline $\begin{array}{l}\text { Kulit Delima Merah } \\
\text { dan Asam Askorbat }\end{array}$ & 0,770 & 0,593 \\
& & \\
\hline
\end{tabular}

Berdasarkan uji Kolmogorov-Smirnov di atas, didapatkan nilai p-value > 0,05 maka data berdistribusi normal. Dengan demikian, memenuhi kriteria uji parametrik ketiga.

Tabel 9. Hasil Uji Homogenitas Varians Nilai $\mathrm{IC}_{50}$ dengan Uji Levene's test

\begin{tabular}{cc}
\hline \hline Sampel & p-value \\
\hline $\begin{array}{l}\text { Kulit Delima Merah } \\
\text { dan Asam Askorbat }\end{array}$ & 0,144 \\
\hline
\end{tabular}

Pada uji homogenitas menggunakan uji Levene's test didapatkan nilai p-value > 0,05 maka dapat disimpulkan bahwa varians dari dua kelompok populasi adalah sama (homogen). Dengan demikian, data tersebut memenuhi kriteria uji parametrik keempat.

Tabel 10. Hasil Uji t Nilai $\mathrm{IC}_{50}$

\begin{tabular}{ccc}
\hline Sampel & $\mathbf{t}$ & p-value \\
\hline $\begin{array}{c}\text { Kulit Delima Merah } \\
\text { dan Asam Askorbat }\end{array}$ & 25,750 & 0,000 \\
\hline
\end{tabular}

Berdasarkan hasil perhitungan, dapat dilihat bahwa didapatkan nilai p-value $<0,05$ yang berarti aktivitas antioksidan pada sediaan bubuk kulit delima merah dengan asam askorbat memiliki perbedaan yang signifikan.

Masker wajah kulit buah delima merah tidak dapat diukur melalui uji DPPH, tetapi dapat dilakukan pendekatan melalui reaksi antara ekstraknya melalui uji DPPH.

Menurut Molyneux (2004), tingkat kekuatan aktivitas antioksidan adalah sangat kuat apabila harga IC50 $<50 \mathrm{ppm}$, kuat apabila harga IC50 50-100 ppm, sedang apabila harga IC50 100-150 ppm, dan lemah apabila harga IC50 150-200 ppm. Semakin kecil harga IC50, maka semakin besar daya peredamannya. Berdasarkan hasil penelitian diperoleh harga IC50 ekstrak etanol kulit delima merah sebesar 8,33 ppm yang termasuk tingkat kekuatan aktivitas antioksidan sangat kuat. Bila dibandingkan dengan kontrol positif, yaitu asam askorbat, maka kekuatan aktivitas antioksidannya lebih rendah. Hal ini 
ditunjukkan dengan harga IC50 asam askorbat sebesar 2,98 ppm yang juga termasuk tingkat kekuatan aktivitas antioksidan sangat kuat.

Pada uji analisis statistik data persen inhibisi, dilakukan uji normalitas data dengan uji Kolmogorov-Smirnov untuk melihat apakah data terdistribusi secara normal. Masingmasing sampel memperoleh hasil p-value $>0,05$ sehingga data terdistribusi normal. Pada uji homogenitas varians nilai p-value masing-masing sampel uji > 0,05 maka dapat disimpulkan bahwa varians dari dua kelompok populasi adalah sama (homogen). Data yang digunakan merupakan data yang memenuhi kriteria uji parametrik sehingga dilakukan uji t, masing-masing sampel memperoleh nilai $\mathrm{p}$-value $<0,05$ yang berarti persen inhibisi sediaan bubuk kulit delima merah dengan asam askorbat memiliki perbedaan yang berbeda secara nyata.

Pada uji analisis statistik data nilai IC50, dilakukan uji normalitas data untuk melihat apakah data terdistribusi secara normal. Masing-masing sampel memperoleh hasil $\mathrm{p}$-value $>0,05$ sehingga data terdistribusi normal. Pada uji homogenitas varians nilai $\mathrm{p}$ value masing-masing sampel uji > 0,05 maka dapat disimpulkan bahwa varians dari dua kelompok populasi adalah sama (homogen). Hasil data nilai IC50 diolah menggunakan uji t. Berdasarkan hasil perhitungan pada uji t didapatkan nilai $p$-value $<0,05$ yang berarti aktivitas antioksidan pada sediaan ekstrak bubuk kulit delima merah dan asam askorbat memiliki perbedaan yang berbeda secara nyata.

Menurut teori Madrigal buah delima merah mengandung senyawa flavonoida, asam fenolat dan tanin yang dapat menyebabkan kuatnya kandungan antioksidan yang terdapat pada buah delima merah.

Senyawa flavonoida sering diketahui manfaatnya sebagai antioksidan, khususnya penangkap radikal bebas. Flavonoida memiliki berbagai kegunaan. Pada tumbuhan flavonoida berfungsi untuk memberikan perlindungan terhadap adanya stres lingkungan, pengaturan pertumbuhan tanaman, perlindungan terhadap radiasi ultraviolet dan daya tarik penyerbuk serangga (Vidak, Rozman, \& Komel, 2015). Pada manusia berfungsi sebagai antibakteri, antiinflamasi, antialergi, antijamur, antitumor, menurunkan hiperlipidemia pada manusia, dan mencegah osteoporosis. Salah satu artikel jurnal pernah menyatakan bahwa kemampuan antioksidan dari flavonoida dapat mengurangi pembentukan radikal bebas dan menangkap radikal bebas.

Asam fenolat merupakan metabolit sekunder yang sering ditemukan pada tanaman. Senyawa asam fenolat mempunyai peranan yang penting pada tumbuhan yaitu sebagai bahan pendukung dinding sel. Asam fenolat merupakan antioksidan yang sangat kuat dan memiliki aktivitas antibakteri, antivirus, antikarsinogenik, antiinflamasi, dan aktivitas vasodilator. Selain itu asam fenolat juga mempunyai peranan untuk melindungi dari kanker dan penyakit jantung.

Senyawa tanin merupakan senyawa yang termasuk golongan flavonoida, karena dilihat dari strukturnya yang memiliki dua cincin aromatik yang diikat oleh tiga atom karbon dan mempunyai beberapa kegunaan di antaranya antioksidan, antibakteri, astringen, dan antidiare.

Penggunaan buah delima merah telah dikembangkan menjadi berbagai macam produk kecantikan seperti masker (peel off mask), toner, dan krim. Banyaknya manfaat dan khasiat tanaman delima merah sebagai antioksidan telah diuji pada penelitian ini di mana hasilnya terbukti bahwa salah satu bagian dari tanaman delima merah yaitu kulitnya mengandung aktivitas antioksidan yang tinggi dan dapat dijadikan ekstrak bubuk. 


\section{Kesimpulan}

Kulit Delima Merah dapat diolah menjadi masker wajah bubuk. Ekstrak kulit delima merah mempunyai aktifitas antioksi dan dan termasuk kategori antioksidan yang sangat kuat, dikarenakan memiliki nilai IC50 sebesar 8,33 ppm. Dari sudut pandang Islam, penelitian tentang "Analisis Aktivitas Antioksidan pada Sediaan Masker Wajah Kulit Buah Delima Merah (Punica granatum L.) Melalui Reaksi Antara Ekstraknya dengan 1,1-Difenil-2-pikrilhidrazil (DPPH) dan Tinjauannya Menurut Pandangan Islam" sejalan dengan perintah Allah SWT yang menyarankan umatnya untuk menjaga kesehatan dan kecantikan diri.

\section{Bibliografi.}

AF, Swaidatul Masluhiya, Widodo, Widodo, \& Widyarti, Sri. (2016). Formulasi Masker Alami Berbahan Dasar Bengkoang dan Jintan Hitam Untuk Mengurangi Kerutan pada Kulit Wajah. Care: Jurnal Ilmiah Ilmu Kesehatan, 4(2), 22-35.

Andarina, Rosi, \& Djauhari, Tantawi. (2017). Antioksidan dalam dermatologi. Jurnal Kedokteran Dan Kesehatan: Publikasi Ilmiah Fakultas Kedokteran Universitas Sriwijaya, 4(1), 39-48.

Fauzi, Tengku Muhammad. (2018). Peran Antioksidan Vitamin C Pada Keadaan Stres Oksidatif Dan Hubungan Dengan Kadar Malondialdehid (Mda) Di Dalam Tubuh. Majalah Ilmiah Methoda, 8(2), 61-67.

Hadinata, Gerardus Danny Yustian. (2015). Optimasi variasi suhu dan waktu ekstraksi ekstrak daun kedondong (Spondias dulcis) terhadap aktivitas antioksidan. UAJY.

Lepir, Emilia Kaita, \& Hadiwibowo, Gardiani Febri. (2019). Mutu Fisik Sediaan Masker Gel Peel Off Ekstrak Biji Buah Durian (Durio zibethinus Murr) Dengan Variasi KonsentrasI PVA 8\%, 10\% dan 12\%. Malang: Akademi Farmasi Putera Indonesia Malang.

Nurliyana, R. D., Syed Zahir, I., Mustapha Suleiman, K., Aisyah, M. R., \& Kamarul Rahim, K. (2010). Antioxidant study of pulps and peels of dragon fruits: a comparative study. International Food Research Journal, 17(2).

Probosari, Niken. (2015). Daya Antibakteri Fraksi n-butanol Kulit Buah Delima Putih (Granati fructus cortex) terhadap Streptococcus mutans (Antibacterial Activity of White Pomegranate Pericarp (Granati fructus cortex) n-butanol Fraction against Streptococcus mutans). Pustaka Kesehatan, 3(3), 536-541.

Riris, Ariyanti. (2018). Pengaruh Variasi Konsentrasi Trietanolamin Terhadap Karakteristik Krim Ekstrak Etanol Daun Nangka (Artocarpus heterophyllus) Sebagai Antioksidan. Semarang: Universitas Wahid Hasyim Semarang.

Rorong, Johnly. (2019). Uji aktivitas antioksidan dari daun cengkeh (Eugenia carryophyllus) dengan metode DPPH. Chemistry Progress, 1(2).

Rummun, Nawraj, Somanah, Jhoti, Ramsaha, Srishti, Bahorun, Theeshan, \& NeergheenBhujun, Vidushi S. (2013). Bioactivity of nonedible parts of Punica granatum L.: a potential source of functional ingredients. International Journal of Food Science, 2013.

Sayuti, Kesuma, \& Yenrina, Rina. (2015). Antioksidan alami dan sintetik. Padang. Universitas Adalas, 40.

Siagian, Priska. (2013). Keajaiban Antioksidan. Gramedia Pustaka Utama.

Sunaryo, M. Kes, Rahayu Wijayanti, S. Kp, Kep, M., Kom, Sp, Kuhu, Maisje Marlyn, SKM, M. P. H., Sumedi, Ns Taat, Widayanti, Esti Dwi, Sukrillah, Ulfah Agus, \& Riyadi, Ns Sugeng. (2016). Asuhan keperawatan gerontik. Penerbit Andi.

Thabathaba'i, M., 1991. Tafsir al-Mizan Fi Tafsir al-Qur'an. Beirut: al-A'lamiy, 145. 
Vidak, Marko, Rozman, Damjana, \& Komel, Radovan. (2015). Effects of flavonoids from food and dietary supplements on glial and glioblastoma multiforme cells. Molecules, 20(10), 19406-19432.

Yuslianti, Euis Reni. (2018). Pengantar radikal bebas dan antioksidan. Yogyakarta: Deepublish.

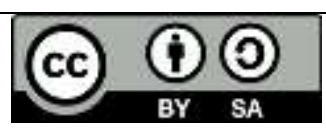

This work is licensed under a Creative Commons Attribution-ShareAlike 4.0 International License. 